\title{
ЕДНА РЕЦЕНЗИЯ ЗА ЗНАЧИМОСТТА НА ЧОВЕШКИТЕ РЕСУРСИ С. Тончева
}

$\mathrm{P}$

ецензията е от проф. д-р Соня Колева Тончева, д.оз.н., директор на филиал Шумен, МУ „Проф. д-р П. Стоянов“ Варна, национален консултант по здравни грижи, научен ръководител на дисертационен труд на тема: Значимостmа на човешките ресурси за успешното развитие на Самостоятелна медико-техническа (зъботехническа) лаборатория, за присъждане на ОНС ,Доктор“ на Ани Атанасова Атанасова - преподавател в Медицински колеж - Варна

Успешно защитеният дисертационен труд на тема: Значимостма на човеиките ресурси за успешното развитие на Самостоятелна медико-техническа (зъботехническа) лаборатория, за присъждане на ОНС „Доктор“ на Ани Атанасова Атанасова - преподавател в Медицински колеж - Варна е поредният, разработен от преподаватели по Зъботехника в МУ,„Проф. д-р П. Стоянов““, Варна.

Избраната тема на дисертационния труд е изключително актуална в момент, когато всеки ръководител се стреми да оптимизира структурата, която ръководи, да привлече качествени специалисти и да произвежда продукт, който да бъде конкурентен на пазара.

Проведеното задълбочено и мащабно проучване, прецизно направеният SWOT анализ и предложеният от авторката Модел за оптимално управление на човешките ресурси в зъботехническа лаборатория за успешното ѝ развитие, биха били полезни за денталната практика и в частност превръщането на зъботехническата лаборатория в успешна и гарантираща качество на протези, шини и други зъботехнически конструкции. Изясняването на участието на управителите на Самостоятелните медико-технически лаборатории (СМТЛ) и зъботехниците в процеса засилва актуалността на избрания за проучване и анализиране проблем.

Според авторката мениджърите следва да полагат повече усилия да усъвършенстват знанията, уменията и нагласите на своите служители, защото това е начинът да формират поведение, което е ориентирано към по-големи постижения и по-голяма производителност.

Изследователският интерес на А. Атанасова да разработи темата за ,Значимостта на човешките ресурси за успешното развитие на Самостоятелна медико-техническа (зъботехническа) лаборатория“, е продиктуван от липсата на достатьчно литературни източници и изчерпателни проучвания по проблема, които да доказват положителното влияние на човешките ресурси за развитието и конкурентоспособността на зъботехническата лаборатория на пазара на труда.

Начинът, по който хората възприемат своята работа, формира индивидуалното им поведение. В тази връзка изключително важна е ролята на ръководителя, който организира работата, като определя какво трябва да се свърши, кога, как и от кого. Когато изборьт на това решение е направен сполучливо и ефективно, ръководителят има реална възможност да координира усилията на работниците и заедно да реализират своите потенциални възможности за решаване на поставените задачи. За да бъде успешен управителят трябва да притежава знания и в областта на управление на човешките ресурси.

Преподавател Атанасова е определила ясно целта на дисертационния труд и са поставени седем задачи за постигането ѝ. Формулирани са три работни хипотези.

Обхванати са 250 лица от Варна, Добрич и Бургас, разпределени в три групи:

І група - управители на зъботехнически лаборатории (зъботехници);

II група - зъботехници, работещи като наемни слу-

жители в зъботехнически лаборатории;

III група - дентални лекари - работещи със зъботехнически лаборатории, в които има наемни зъботехници.

Прецизно са определени критериите за включване на респондентите от трите групи. Детайлно в табличен вид са представени 7-те етапа на научното проучване, като са посочени време, място, съответно с приложения инструментариум и броя на обхванатите респонденти. Инструментариумът на проучването (анкетните карти) е обстойно представен. Надеждно са подбрани методите на научното проучване (исторически, документален, социологически, SWOT анализ), които гарантират достоверност на получените резултати. При обработка на данните е използван статистическия софтуерен пакет - IBM SPSS за Windows, v.20.0. При всички проведени анализи се приема допустимо ниво на значимост $\mathrm{p}<0.05$ при доверителен интервал 95\%.

Научното проучване и получените резултати дават основание авторката да установи основните качества, които трябва да притежава управителят на зъботехническа лаборатория: професионализъм (дентални лекари - 100\%, зъботехници - 95,24\% и управители - 91,38\%), коректност към работниците $(90,91 \%$ - дентални лекари, 92,86\% - зъботехници и 93,10\% - управители).

Атанасова изследва предпочитани от зъботехниците стимули при полагане на извънреден труд и доказва, че са материалните (96.55\% - управители и 87.30\% - наемни работници), докато $95.45 \%$ от лекарите по дентална медицина посочват нематериалните стимули. Според резултатите и за трите групи предпочитана форма за повишаване на квалификацията са краткосрочните курсове (71.67\% - дентални лекари, 61.90\% - зъботехници и 55.17\% - управители).

В търсенето на отговори относно мениджмънта на успешната лаборатория Атанасова установява, че за поддържане на добрия микроклимат в зъботехническата лаборатория от съществено значение според трите групи изследвани лица е уважението към ръководителя и между колегите (над 90\%). Тя не пропуска да обсьди факторите, които оказват влияние върху текучеството на персонала, като доказва, че управителите $(82,76 \%)$ и зъботехниците $(69,84 \%)$ посочват ниското заплащане, а според лекарите по дентална медицина важен фактор са конфликтите $(92,42 \%)$. Според лекарите по дентална медицина $(95,45 \%)$ и управителите $(93,10 \%)$ за оптимизиране на работния процес комуникацията има основна роля, докато за зъботехниците $(91,27 \%)$ тя е еднакво важна за подобряване на качеството на работа и за създаване на по-добра работна атмосфера $(91,27 \%)$. Авторката прави важно заключение, че зъботехникът трябва да притежава освен добри професионални умения и редица личностни качества (мотивация, отговорност, организираност, дисциплинираност), необходими за работа в екип и предоставяне на качествени дентални грижи за пациентите.

В резултат на проучената литература, проведените социологически изследвания и направеният SWOT анализ А. Атанасова прави в края на всяка глава от дисертационния труд детайлни изводи.

В резултат на всички проведени анализи авторката създава и предлага Модел за оптимално управление на човешките ресурси в зъботехническа лаборатория за успешното ѝ развитие, който ѝ дава възможност да бъдат направени основни насоки за създаването и функционирането на ефективен екип и подобряването на работния процес ( $\boldsymbol{\Phi} \boldsymbol{u}$ гура 1).

За създаване на Модела А. Атанасова се позовава на опита на организации, които са световни лидери в органи- 
зацията на управлението на човешки ресурси (класация на списание „Fortune“ за 2017 г. за „най-добрите места за работа“, обхващаща организации в сферата на услугите). Атанасова прецизно се фокусира и взема предвид спецификата на организационните процеси в зъботехническата лаборатория, поради малката численост на персонала и наличието (в повечето случаи) на един управител, в чието лице са съсредоточени всички функции и дейности по управление на човешките ресурси. По този начин тя създава своя Модел като търси подобрения в различни управленски аспекти.

Фигура 1. Модел за оптимално управление на човешките ресурси в зъботехническа лаборатория за успешното ѝ развитие

1. Кадрово осигуряване на СМлт

2. Обучение и възможности за професионално развитие на зъботехниците

3. Мотивация на зъботехниците

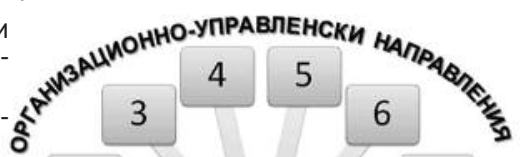

4. Управление на конфликтите и поддържане на добър микроклимат

2

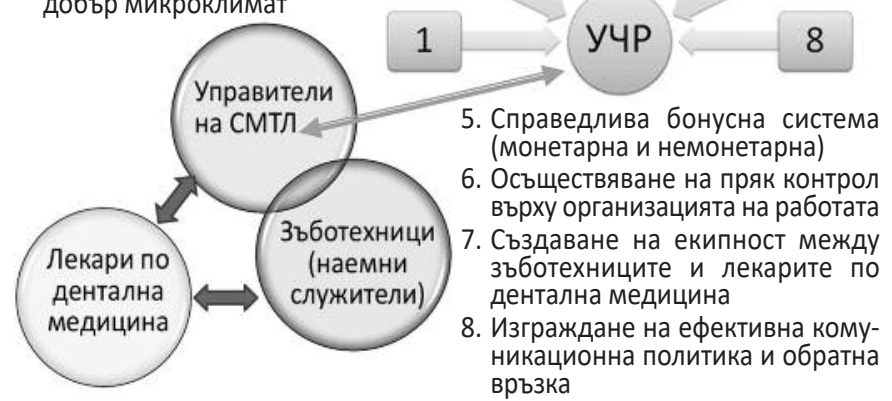

Направени са детайлни изводи и препоръки, които се основават на доказаните с научното проучване резултати, точно адресирани към институции и структури, имащи отношение към проблема. Особено внимание заслужават направените препоръки за обособяване на Национален регистър на практикуващите зъботехнищи в България и въвеждане на изискване за заемане на дльжност ,, Управител на СМТЛ“6 - квалификационен курс по здравен мениджмънт с минимум 80 часа.

Резултатите от научното проучване, формулираните изводи и препоръки очертават приноси с теоретично и приложно значение, от които най-важни са:

1. Изследвана е значимостта на човешките ресурси за успешното развитие на Самостоятелна медико-техническа (зъботехническа) лаборатория.

2. Направен е задълбочен сравнителен анализ на качествата, които трябва да притежават зъботехниците и управителите, за да са успешни в съвременните условия на технологичен напредък.

3. Разработен е теоретичен Модел за оптимално управление на човешките ресурси в зъботехническа лаборатория за успешното ѝ развитие.

4. Направен е SWOT-анализ на зъботехническа лаборатория.

5. Проученото мнение на управители, зъботехници и лекари по дентална медицина за пръв път у нас фокусират вниманието към управление на зъботехническата лаборатория и значимостта на човешките ресурси.

6. Разработеният Модел за оптимално управление на човешките ресурси в зъботехническа лаборатория за успешното ѝ развитие е с потенциал за прилагане в реална работна среда и включване на спецификата на различни СМТЛ (брой наемни работници, прилагани технологии и др.).

$$
* *
$$

\section{Огромните чертози на паметта (свети Августин)}

Със своите Изповеди свети Августин се впуска в една мащабна интроспекция в желанието си напълно да се открие пред Бога, за да достигне до истината в своето сърце и да се обрисува такъв, какъвто е. Защото „никой човек не знае какво има в човека освен човешкия дух, който живее в него“, макар че „душата е тясна сама себе си да обхване“. Така найдобният начин да опознаеш себе си е в това да пребродиш огромните чертози на паметта, „тайник обширен и безкраен, където се намират съкровища от неизброими образи, внесени от усещанията за всяка една вещ“. Именно там, допълва той, „и себе си аз срещам и за себе си си припомням - какво, кога и къде съм правил нещо и по какъв начин съм изпитал въздействието тогава“.

Свети Августин различава три типа памет: памет на сетивата, памет на интелекта и памет на чувствата. В първата са съхранени и подредени по видове усещанията, които са навлезли всяко по своя път: светлината, цветовете и формите чрез очите; звуците чрез ушите; ароматите чрез ноздрите; вкусовете чрез устата и накрая всички сетивни възприятия чрез тактилните усещания. Очевидно обаче, отбелязва свети Августин, в паметта влизат не самите неща, а образите на сетивните неща, поставяйки се под властта на мисълта, която ги извиква. Тази способност на мисълта да поражда спомените буди велика почуда, тъй като и в най-дълбокия мрак човек е в състояние да си представи цветове, образи и дори усещания, единствено извиквайки ги в паметта си. Силата на тези образи се дължи на факта, че тези изображения на миналото са изображения в настоящето: така, когато свети Августин си спомня и разказва за своето детство, той го вижда в настоящето. „Паметта е настоящето за миналото“.

Тази памет на сетивата не е единствената. Съществува също така и паметта на разума, съдържаща всичко онова, което е усвоено от науката и подредено, „но някак по-навътре и не на място вместени“. ... Именно паметта е тази, която ни прави способни да съдим за истинното и неистинното, за доброто и злото, за красивото и грозното

Жоел Кандо, „Антропология на паметта”, изд. къща „Одри”, 2001 